\section{Gvozdeva I., Lukovtsev V., Tierielnyk $\mathbf{5}$.}

\title{
FORECASTING OF THE PERFORMANCE OF THE SHIPBOARD ELECTRIC POWER SYSTEM ON THE BASIS OF THE ARTIFICIAL NEURAL NETWORK
}

Розроблена структура системи прогнозування стану суднової електроенергетичної системи (СЕЕС) на базі штучної нейронної мережі (ШНМ). Вирішена задача навчання ШНМ, використовуючи данні, отримані в результаті застосування аналітичних методів прогнозування стану СЕЕС. Доведена можливість застосування ШНМ для вирішення задач прогнозування стану СЕЕС.

Ключові слова: прогнозування стану суднової електроенергетичної системи, коефіцієнт узагальненого параметра, итучна нейронна мережа.

\section{Introduction}

Analysis of the causes of accidents of shipboard electric power systems (SEPS) [1] shows that a significant part of them occurred due to untimely definition of the pre-emergency condition, as well as incorrect and ineffective actions of the crews of sea-going vessels during the accident itself. Therefore, one of the tasks in creating an effective management system is development and improvement of software and hardware structures that facilitate the accumulation and analysis of information on the state of the SEPS in order to prevent accidents.

\section{The object of research and its technological audit}

The object of research is the process of forecasting the SEPS operation. To reduce the likelihood of SEPS accident occurrence, automation systems can solve the tasks of not only traditional monitoring, but also prediction tasks for the possibility of successful management in pre-emergency, emergency and post-emergency operation modes.

The work of the SEPS is controlled by the regime parameters (voltage, power, frequency, etc.) through the monitoring system.

Since the processes taking place in the SEPS can be controlled by a set of parameters that vary according to certain laws:

$$
x_{1}, x_{2}, \ldots, x_{n},
$$

then the external information characteristics of the process or regime can be represented as a set of vectors or a matrix that unambiguously displays the state of the process at fixed times:

$$
X^{*}=\left|\begin{array}{cccc}
x_{1}\left(t_{1}\right) & x_{1}\left(t_{2}\right) & \ldots & x_{1}\left(t_{k}\right) \\
x_{2}\left(t_{1}\right) & x_{2}\left(t_{2}\right) & \ldots & x_{2}\left(t_{k}\right) \\
\ldots & \ldots & \ldots & \ldots \\
x_{n}\left(t_{1}\right) & x_{n}\left(t_{2}\right) & & x_{n}\left(t_{k}\right)
\end{array}\right| .
$$

The parameter vector describes a certain trajectory that allows to investigate the behavior of the object and in the long term to determine the state and operating mode of the SEPS.

Forecasting the SEPS efficiency consists in evaluating its parameters based on measurement data coming from the objects of control into operational computer-based information systems based on mathematical methods of data processing, which in most cases are reduced to solving linear deterministic multiparameter problems, based on forecasting methods. Broad use, with operational control, data on the status of the operation mode of the object makes high demands on the speed of information and computing systems. The pace of solving real-time problems is very high, since the amount of processed information reaches tens of thousands or more of analog measurements with a 1-10 second acquisition cycle. At the same time, the level of methodological and algorithmic developments has reached a state where the main limiting factor in optimizing the process of forecasting the SEPS operation is the performance of a computer. In this regard, there is a need to develop automation tools that will expand the range of functions they perform.

\section{The aim and objectives of research}

The aim of research is development of a system for forecasting the SEPS state based on an artificial neural network (ANN).

To achieve this aim, the following tasks are set:

1. Normalization of data characterizing the SEPS state.

2. Selection of topology and learning of ANN.

\section{Research of existing solutions of the problem}

Methods of forecasting indicators characterizing the state of technical objects have always been given great attention. In most cases, the analysis is based on a number of statistical methods [2]: correlation, regression and factor; 
econometric and heuristic; time and spatial extrapolation; modeling of development processes.

According to researchers [2-5], the number of different prediction methods and techniques has exceeded 400 . However, the number of basic procedures, repeated in various variations in other methods, does not exceed a dozen. The specifics of the initial information and the analyzed object require the choice of an adequate method in development of forecasting systems. Since the aim of this work is development of a system for forecasting the SEPS operation, then the analysis of forecasting methods will concern only those methods that are expedient for applying in technical systems.

Thus, the method of heuristic prediction was considered in [6]. In a broad sense, heuristic forecasting consists in an intuitive choice of the most important and decisive factors from an infinite number of circumstances. The basic procedure for forecasting is comparison of all the values and options by which all the unimportant and insignificant is eliminated. The effectiveness of heuristic forecasting methods is increased not due to their internal structure, but due to external design: selection of relevant qualifications and the number of experts, as well as improving the algorithms for processing the results of the survey. In accordance with this, methods of individual peer reviews are developed, such as interviews and analytical assessments. The basic methods of collective peer review include the methods of commissions, collective generation of ideas, the matrix method, and others [2].

However, heuristic methods are subjective and suitable only when there are experts who are well acquainted with the foreseen situation. In addition, when predicting the characteristics of complex technical facilities, such as the SEPS, heuristic forecasting methods become very complex and time-consuming.

This circumstance required the development of mathematical prediction methods. The main advantages of such methods are the objectivity of obtained information and the possibility of automating the forecasting process using a computer.

Depending on the used mathematical apparatus and the target orientation, the mathematical methods of temporal extrapolation can be conditionally divided into three groups:

1) methods of analytical forecasting;

2) methods of probabilistic forecasting;

3) methods of statistical classification.

In those cases when the controlled process is «informative» in time [7], the forecasting problem can be solved by various methods called analytical forecasting methods and differing by the used mathematical device. There are a number of analytical prediction methods that take into account the derivatives of the state function changes. Among such methods are the operator method [8], the summation method for derivatives [9] and other methods. The prediction models that take into account the derivatives of the functional state have an uncertainty of the initial conditions, therefore, with random noise, the initial uncertainty increases, which make it difficult to determine the model parameters. As a consequence, the accuracy of forecasting is deteriorating. The most common predictive analytical method is the method based on the application of basic functions, which is suitable for describing a monotonous and gradual change in parameters $[10,11]$. The disadvantages of this method include the complexity and laboriousness of the calculations associated with the need to select and calculate a predictive analytic expression for each parameter.

The general shortcomings of analytical forecasting methods include a large amount of computational procedures in determining the predicted values of the parameters, as well as inaccuracy of the prediction results with the wrong model. In addition, account must be taken of inaccuracies in the initial data obtained during the observation period.

The need for probabilistic forecasting is determined by the strong influence of external and internal factors that have a random character. Probabilistic prediction methods include, for example, the statistical gradient method [12]. The method using the Bayesian criterion makes it possible to determine the density distribution of the gradient vector of the state function [13]. To determine the most probable direction of the gradient in this case, the distribution of increments for each coordinate of the state function vector is constructed. The method of hypotheses and filtering is that a hypothesis about this or that behavior of the function is introduced, and then all the results of control and forecasting that do not satisfy the accepted hypothesis are filtered out. The disadvantage of forecasting systems using these methods is low efficiency due to inertia in obtaining the forecast results.

In the framework of the following method, the distribution function of parameters with predominance of random components is considered [14]. The prediction of changes in this function consists in the calculation of statistical characteristics and the construction of integral distribution functions of different sequences of time series. An essential shortcoming of the method is the need for long-term monitoring with individual prediction to obtain representative samples.

To obtain a continuous prediction, the optimal filters are used: the Wiener-Hopf filter [15] for predicting stationary processes and the Kalman filter [16] for non-stationary processes. The principal difficulties in applying these filters are the cumbersomeness of computational procedures and the need for representative statistical data. The statistical regression method allows one or several quantities to be predicted based on information about the parameters of the object. The task is determination of such function of the model, knowing that it is possible to judge with some certainty the change in the forecasted value depending on the arguments [17]. This method is objective, but requires a number of conditions for successful application. First of all, a fairly large amount of statistical data obtained at the observation site is needed. In addition, it is necessary to know the type of deterministic basis of the process or function that describes the process of changing parameters. The biggest disadvantage of the method is the impossibility of predicting a qualitative change in the nature of dynamics of the technical state of the object, i. e., the jump.

The need for a representative amount of statistical data on the process of changing parameters and the inability to predict sharp changes in the forecasting area can be attributed to the general shortcomings of most forecasting systems using probabilistic methods.

Predictive systems based on methods of statistical classification are widely used. In [18] exponential smoothing is used-the Box-Jenkins method. The Box-Jenkins model [17] is based on the processing of autoregressive series in 
which no a priori assumptions are made about discounting coefficients. In this case, the transition to the differences in the series is used and the residuals are correlated with the representation of their moving average [11]. The prediction algorithm is a second-order filter.

A method based on spectral analysis is considered in [2]. The spectrum of the time dependence of a function is the set of its harmonic components that form the Fourier series. Spectral analysis provides the ability to calculate the amplitude and phase of any harmonic (or spectral density at any frequency). Based on the expansion of the time series into components, a method of spectral decomposition has been developed to account for various regular oscillations. If regular changes are selected from the actual values, the residual series will represent fluctuations in the values of the parameters relative to the systematic changes caused by the influence of local factors.

To simulate different processes, the Monte Carlo method based on the use of random numbers is applied [19]. A generalized algorithm for implementing the Monte Carlo method provides prediction of the operation of the object and calculation of the statistical characteristics of its functional parameters. The accuracy of the predicted values is estimated in two ways: a priori and a posteriori [20]

An essential shortcoming of all forecasting systems based on the method of statistical classification can be considered mandatory availability of a priori information on the basis of which the establishment of temporary extrapolation links is carried out. In fact, it is necessary to select data for an object of the same type with the object whose indicators is necessary to predict.

Recently, considerable interest has been shown in methods based on nonlinear models. Most of these methods belong to the category of artificial intelligence technologies [21]. These are, first of all, artificial neural networks and the latest optimization tools, including, for example, genetic algorithms [22, 23], an annealing modeling method [24] and others [25-27].

\section{Methods of research}

As a research method, the computer simulation method is chosen, which today is one of the main methods for studying complex systems and physical processes.

\section{Research results}

\subsection{Normalization of input data} (rationing of parameters). Due to the fact that the regime of a technical object is characterized by parameters of different physical nature that have different dimensions, all parameters are reduced to a single number system, which is the system of dimensionless (normalized) relative numeration.

If for each parameter $x_{n}, n=$ $=1,2 \ldots$, it is possible to select the allowable $x_{n}^{*}$, and the optimal (nominal) $x_{o p t}$ value, then the dimensionless parameter can be written in the form [28]:

$$
\hat{x}_{n}(t)=\frac{x_{n}(t)-x_{n}^{*}}{x_{\text {opt }}-x_{n}^{*}}
$$

where $0 \geq x_{n}(t) \geq 1$ at $x_{n}(t)=x_{\text {opt }} \quad \hat{x}_{n}(t)=1$, and at $x_{n}(t)=x_{n}$, $\hat{x}_{n}(t)=0$.

The normalized parameter $x_{n}(t)$ in the form of a dimensionless normalized quantity $\hat{x}_{n}(t)$ changes with time from 0 to 1 when the parameter $x_{n}$ changes from $x_{o p t}$ to $x_{n}^{*}$, allowing to judge the degree of availability of the object mode with respect to this parameter.

6.2. The problem of SEPS modes classification. The mode of operation of the object is controlled by the deviation of the operating parameters from the established norm, an alarm is raised when the parameter value is increased.

There is a need for forecasting in order to be able to make preventive management of the facility in order to prevent SEPS transition to the pre-emergency regime.

The analysis of information about the operating modes of the technical object consists in the classification of signals from the sensors and the assignment of the perceived set of parameters (3) to the region characterizing one of the technical conditions of the object «Fault-free», «Warning», «Failure».

$$
\mathrm{X}=\left(\mathrm{x}_{1}, \mathrm{x}_{2}, \ldots . \mathrm{x}_{n}\right) .
$$

For this purpose, the parameter space is partitioned by some criterion into n-domains (4).

$$
\mathrm{X}_{1}, \mathrm{X}_{2}, \ldots \mathrm{X}_{i}
$$

The vector $\mathrm{X}_{i}$ in the space of attributes (parameters) is called the implementation vector.

Thus, the problem of recognizing technical states is formulated as a problem of classifying images.

6.3. Implementation of the ANN-based forecasting system. The effectiveness of the application of neural networks lies in the possibility of parallelizing the processing of information and the ability to self-learn, i. e., to create generalizations. These properties make it possible to improve the speed of system management in the identification of the SEPS regime and its subsequent prediction. In Fig. 1 shows the structural diagram of the implementation of the system for the prediction of the SEPS operation, where the ADs are the amplification devices, NDs are the normalizing devices that bring the physical parameters of a different nature to a single measurement system (relative units), IPU is the information representation unit.

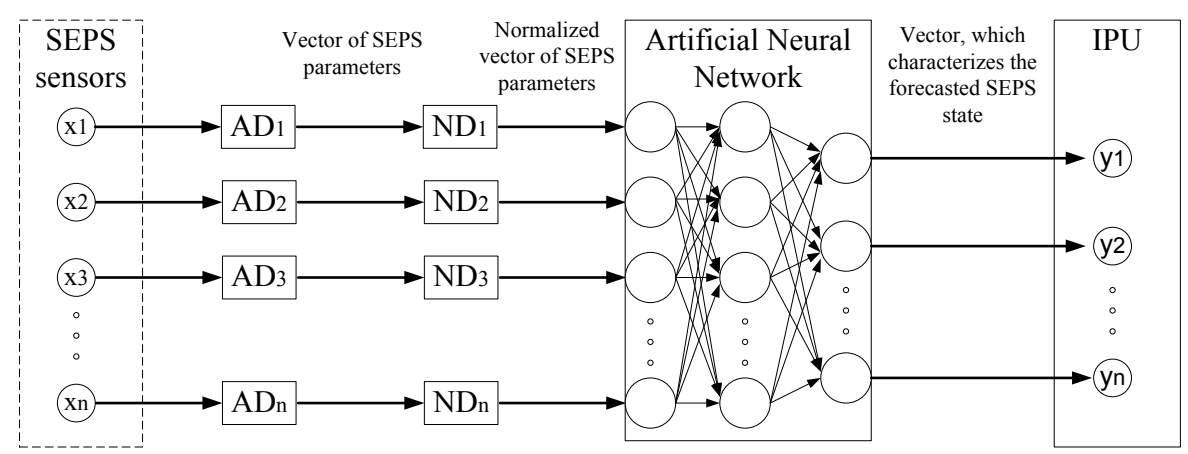

Fig. 1. Structure of the implementation of the system for predicting the SEPS performance on the basis of artificial neural networks 
The choice of the neural network topology depends on the initial data and the type of the problem. At present, there are many types of ANN that differ in structure, as well as algorithms and learning methods [29, 30]. But since the initial data processed by the ANN are a time series consisting of the values of the SEPS parameters, which are measured at a certain time interval (the fraction of a second, second, minute, etc.), the architecture of the multilayer perceptron is the basic [31].

6.4. ANN learning. The type of learning is determined by the way in which these parameters are adjusted. The block diagram of the ANN learning process is shown in Fig. 2.

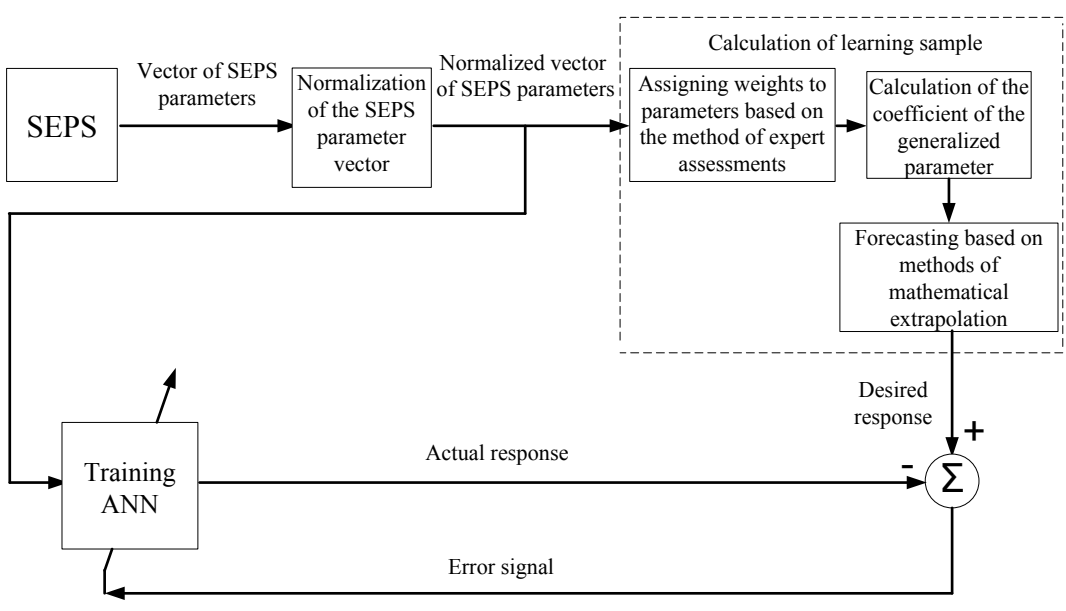

Fig. 2. Block diagram of ANN learning

Fig. 2 is a block diagram illustrating the ANN learning process. The parameter vector describing the SEPS state is fed to the unit for normalizing the values of the parameters. Further, the vector of normalized parameters is fed to the learning block (the learning sample calculation block for the ANN). Since quantitatively the same values of these quantities are not equivalent in terms of the degree of influence on the change in the mode of the object, they must be differentiated, that is, take into account the degree of influence of each parameter on the operating mode of the object. This is achieved by introducing positive weights $\mu_{\mathrm{i}}$ of controlled parameters, the values of which characterize the significance of the relevant parameters. Weights can be obtained by the method of peer evaluation [32, 33]. Then the coefficient of the generalized parameter is calculated. To determine the generalized parameter $\mathrm{Q}_{\Sigma}$, it is most expedient to use the formula developed in [32]:

$$
Q_{\Sigma}=\frac{\left(\prod_{i=1}^{n} \hat{x}_{i}^{M_{i}}\right) n^{\frac{1}{2}}}{\left[\sum_{i=1}^{n}\left(\hat{x}_{i}^{M_{i}}\right)^{2}\right]^{\frac{1}{2}}}
$$

where $i$ - the number of parameters; $\hat{x}_{i}$ - the normalized value of the parameter; $\mu_{i}$-the weight of each parameter.

Further, in the presence of several consecutive measurements and predicted values of the generalized parameter made at regular intervals, their processing can reveal trends in their future changes. That is, perform a prediction of the value of the generalized parameter for the next cycle, or when this parameter reaches the alarm value.

The prognostic control of the parameters is related to the measurement of the rate of its change and the subsequent extrapolation of its value in order to establish the time period through which the emergency situation may occur (the limiting value of the monitored parameter).

Considering the fact that the processes in the SEPS are relatively inertial, one can identify a tendency to change them by the extrapolation method. Since measurements and calculations of the generalized parameter are made at regular intervals, it is possible to use not the time but the measurement number as a function.

The interpolation or extrapolation function is an analytical form of representing this trend under the assumption that it remains unchanged at some point in time. This allows to assert that for a physical object, it is possible to predict the change in its parameters, since the latter possesses inertia.

Various methods of finding such functions are known. The simplest method is selection of a polynomial that approximates this function and has minimal variations (deviations). Usually, polynomials of 1-2-3 degree are used [34].

The obtained data on the basis of the calculations described above can be considered as the presence of knowledge about the object under consideration (SEPS), represented as pairs of input-output vectors, that is, the calculation results are used as a learning sample for ANN. At the same time, there is no preliminary information on SEPS. Now let's suppose that the forecasting calculation block and the trained ANN are given a learning vector characterizing the SEPS state. Based on the calculations, it is possible to generate and transmit to the trained neural network a desired response corresponding to a given input vector. This desired result represents the optimal actions that a neural network must perform. The network parameters are adjusted taking into account the learning vector and the error signal - the difference between the desired signal (the result of calculations) and the current response of the neural network. The error signal can be represented in the form [29, 30]:

$$
e_{i}=y_{i}-y_{i}
$$

where $e_{i}$ - the error signal; $y_{i}-$ desired ANN response; $y_{i}-$ actual ANN response.

The parameters are adjusted step by step, using the algorithm for back propagation of the error [29-31], for the purpose of simulating neural network calculations. Thus, in the learning process, «knowledge», obtained as a result of calculations, is transmitted to the network as fully as possible.

6.5. Program implementation and research results. For the software implementation, the NeuroPro program is selected [35].

As the learning set, the data obtained as a result of calculating the coefficient of the generalized parameter are taken (Table 1). 
Results of calculations and prediction of values of the coefficient of the generalized parameter

\begin{tabular}{|c|c|c|c|c|c|c|c|}
\hline No. & Calculated value K gp & Predicted value K gp & Network error & No. & Calculated value $\mathrm{K}$ gp & Predicted value K gp & Network error \\
\hline 1 & 0.69 & 0.758191 & -0.06819 & 26 & 0.48 & 0.444702 & 0.035298 \\
\hline 2 & 0.75 & 0.804624 & -0.05462 & 27 & 0.17 & 0.250088 & -0.07009 \\
\hline 3 & 0.54 & 0.582284 & -0.04228 & 28 & 0.57 & 0.611471 & -0.04147 \\
\hline 4 & 0.47 & 0.4749 & -0.0049 & 29 & 0.94 & 0.894154 & 0.045846 \\
\hline 5 & 0.59 & 0.514547 & 0.075453 & 30 & 0.88 & 0.895011 & -0.01501 \\
\hline 6 & 0.62 & 0.66301 & -0.04301 & 31 & 0.71 & 0.632607 & 0.077393 \\
\hline 7 & 0.64 & 0.5952 & 0.0448 & 32 & 0.75 & 0.740126 & 0.009874 \\
\hline 8 & 0.35 & 0.320202 & 0.029798 & 33 & 0.89 & 0.885151 & 0.004849 \\
\hline 9 & 0.46 & 0.414705 & 0.045295 & 34 & 0.45 & 0.402151 & 0.047849 \\
\hline 10 & 0.66 & 0.714201 & -0.0542 & 35 & 0.43 & 0.503842 & -0.07384 \\
\hline 11 & 0.53 & 0.55233 & -0.02233 & 36 & 0.56 & 0.604389 & -0.04439 \\
\hline 12 & 0.73 & 0.657219 & 0.072781 & 37 & 0.72 & 0.715954 & 0.004046 \\
\hline 13 & 0.78 & 0.855662 & -0.07566 & 38 & 0.76 & 0.747111 & 0.012889 \\
\hline 14 & 0.89 & 0.899138 & -0.00914 & 39 & 0.54 & 0.533387 & 0.006614 \\
\hline 15 & 0.45 & 0.51241 & -0.06241 & 40 & 0.83 & 0.856239 & -0.02624 \\
\hline 16 & 0.67 & 0.745447 & -0.07545 & 41 & 0.56 & 0.618142 & -0.05814 \\
\hline 17 & 0.77 & 0.774431 & -0.00443 & 42 & 0.8 & 0.795159 & 0.004841 \\
\hline 18 & 0.44 & 0.410835 & 0.029165 & 43 & 0.28 & 0.305724 & -0.02572 \\
\hline 19 & 0.56 & 0.535118 & 0.024882 & 44 & 0.8 & 0.820306 & -0.02031 \\
\hline 20 & 0.48 & 0.525441 & -0.04544 & 45 & 0.71 & 0.74213 & -0.03213 \\
\hline 21 & 0.66 & 0.682068 & -0.02207 & 46 & 0.66 & 0.698864 & -0.03886 \\
\hline 22 & 0.54 & 0.596129 & -0.05613 & 47 & 1 & 0.951718 & 0.048282 \\
\hline 23 & 0.84 & 0.859505 & -0.0195 & 48 & 1 & 0.951718 & 0.048282 \\
\hline 24 & 0.7 & 0.712668 & -0.01267 & 49 & 1 & 0.951718 & 0.048282 \\
\hline 25 & 0.87 & 0.863708 & 0.006292 & 50 & 1 & 0.951718 & 0.048282 \\
\hline
\end{tabular}

Fig. 3 is a graph of calculated (Kgp c) predicted (Kgp p) values of the coefficient of the generalized parameter, on which it is possible to clearly see the accuracy of the forecast.

To estimate the forecast results, the mean absolute error value (7) is used:

$$
e_{M A E}=\frac{1}{n} \sum_{i=1}^{n}\left|K_{g p c}-K_{g p}\right| \text {, }
$$

where $\mathrm{e}_{\mathrm{MAE}}$ - the mean absolute error; $K_{g p c}, K_{g p p}$ - the calculated and predicted values of the coefficient of the generalized parameter, respectively.
The value on the test set is $3.8 \%$, which on the whole shows the correctness of the obtained model.

\section{SWOT analysis of research results}

Strengths. In comparison with similar systems based on deterministic methods of information processing, the use of the ANN-based system provides the following useful properties of forecasting systems:

- nonlinearity;

- adaptability;

- obvious answer;

- fault tolerance;

\section{- scalability;}

- uniformity of analysis and design.

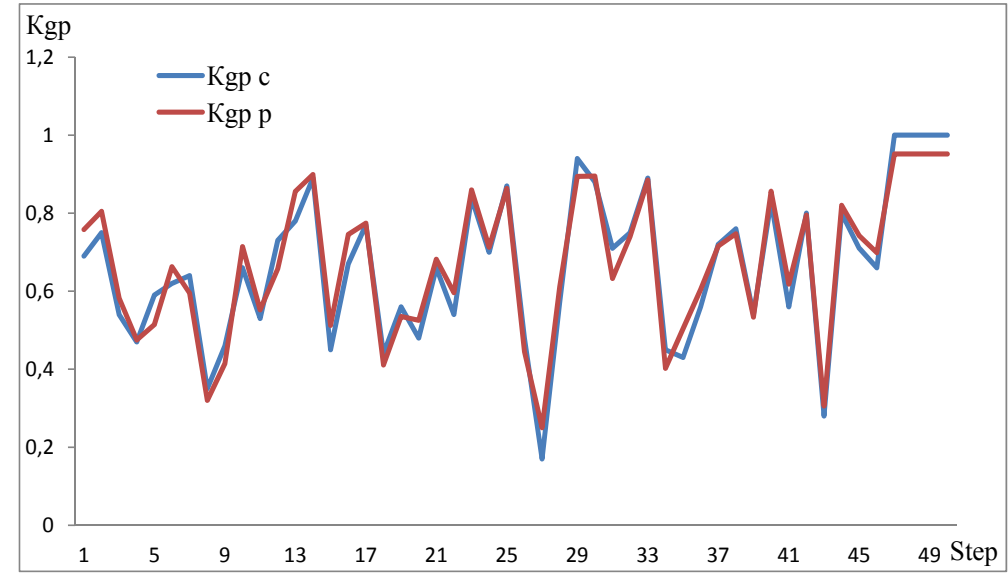

Fig. 3. Calculated and predicted values of the coefficient o the generalized parameter
Weaknesses. The use of ANN in solving complex problems does not always lead to qualitative solutions. At present, there is no formalized theory for optimizing the structure of neural networks or assessing the impact of the network architecture on the representation of knowledge in it. The answers to these questions are usually obtained experimentally.

Opportunities. The forecasting ANN-based system will provide an increase in the calculation speed and, as a consequence, the volume of information processed per unit time. This will reduce the hardware cost and expand the nomenclature of the functions of ship automation that are necessary to ensure accident-free SEPS operation. 
Threats. Regardless of how the network architecture is selected, knowledge about the subject area is allocated to the ANN in the learning process. This knowledge is represented in a compactly distributed form of the weights of the synaptic network connections. This form of knowledge representation allows the neural network to adapt and perform generalization, but does not provide a full description of the computational process used to make a decision or generate an output signal. This leads, as a consequence, to an increase in the time required to select the optimal system settings. Also, the negative side is the need for additional learning costs for personnel providing maintenance of this kind of systems.

\section{Conclusions}

1. It is established that mathematical methods for temporary extrapolation can be used to determine the composition of the input parameters of a neural network and the formation of a rational training sample, when creating systems for the prediction of the ANN-based SEPS operation.

2. It is shown that the system of ANN-based SEPS forecasting has a high approximating ability and allows processing of statistical information, performing forecast estimates. This is confirmed by the results of control forecasting. At the same time, the mean absolute error of forecasting is $3.8 \%$, which makes it possible to judge the possibility of using multilayer neural networks in the development of systems for forecasting the SEPS operation.

\section{References}

1. MAIB Marine Accident Investigation Branch [Electronic resource]. - Available at: \www/URL: http://www.maib.gov.uk

2. Bunn, D. W. Comparative Models for Electrical Load Forecasting [Text] / ed. by D. W. Bunn, E. D. Farmer. - Wiley, 1985. - 242 p.

3. Zakariukin, V. P. Modelirovanie i prognozirovanie protsessov elektropotrebleniia na zheleznodorozhnom transporte [Text] V. P. Zakariukin, A. V. Kriukov, N. V. Raevskii, D. A. Yakovlev; ed. by A. V. Kriukov. - Irkutsk, 2007. - 115 p.

4. Emelianov, A. S. Ekonometriia i prognozirovanie [Text] A. S. Emelianov. - Moscow: Ekonomika, 1985. - 306 p.

5. Singh, A. K. An Overview of Electricity Demand Forecasting Techniques [Text] / A. K. Singh, I. S. Khatoon, M. Muazzam, D. K. Chaturvedi // Network and Complex Systems. National Conference on Emerging Trends in Electrical, Instrumentation \& Communication Engineering. - 2013. - Vol. 3, No. 3. P. $38-48$.

6. Garde, V. D. Technological forecasting for power generation A study using the Delphi technique [Text] / V. D. Garde, R. R. Patel // Long Range Planning. - 1985. - Vol. 18, No. 4. P. 73-79. doi:10.1016/0024-6301(85)90087-1

7. Venttsel, E. S. Teoriia veroiatnostei [Text]: Handbook / E. S. Venttsel. - Ed. 6. - Moscow: Vishcha shkola, 1999. $576 \mathrm{p}$.

8. Wailly, O. Algebraic Observability Analysis of Electrical Network with Symbolic Computation: Application on MYRTE Electrical Power Plant [Text] / O. Wailly, N. Heraud, E. J. R. Sambatra // IFAC Proceedings Volumes. - 2014. Vol. 47, No. 3. - P. 1085-1089. doi:10.3182/20140824-6za-1003.01782

9. Gordunovsky, V. A Summation Constraint Method for Linear Programming [Text] / V. Gordunovsky // Procedia Computer Science. - 2015. - Vol. 55. - P. 246-250. doi:10.1016/ j.procs.2015.07.039

10. Box, G. E. P. Time Series Analysis: Forecasting and Control [Text] / G. E. P. Box, G. M. Jenkins, G. C. Reinsel, G. M. Ljung. - Ed. 5. - Wiley, 2015. - 712 p.
11. Smoliak, S. A. Ustoichivye metody otsenivaniia [Text]/S. A. Smoliak, B. P. Titarenko. - Moscow: Statistika, 1980. - 208 p.

12. Alencar, R. J. N. A method to identify inrush currents in power transformers protection based on the differential current gradient [Text] / R. J. N. Alencar, U. H. Bezerra, A. M. D. Ferreira // Electric Power Systems Research. - 2014. - Vol. 111. P. 78-84. doi:10.1016/j.epsr.2014.02.009

13. Mitiushkin, K. G. Telekontrol' i teleupravlenie v energosistemah [Text] / K. G. Mitiushkin. - Moscow: Energoatomizdat, 1990. - 287 p.

14. Myzin, A. P. Metody i modeli prognozirovaniia dlia razvitiia elektroenergeticheskih sistem $\mathrm{v}$ usloviiah neopredelionnosti i mnogokriterial'nosti [Text]: Dissertation of the Doctor of Technical Sciences / A. P. Myzin. - Novosibirsk, 1994. - 307 p.

15. Kozub, D. J. Multivariable Control of a Catalytic Tubular Reactor Using Both Wiener-hopf Controller Design and Internal Model Controller Design Approaches [Text] / D. J. Kozub, J. F. MacGregor, J. D. Wright // IFAC Proceedings Volumes. 1986. - Vol. 19, No. 15. - P. 285-293. doi:10.1016/s14746670(17)59436-7

16. Singh, S. K. Several variants of Kalman Filter algorithm for power system harmonic estimation [Text] / S. K. Singh, N. Sinha, A. K. Goswami, N. Sinha // International Journal of Electrical Power \& Energy Systems. - 2016. - Vol. 78. P. 793-800. doi:10.1016/j.ijepes.2015.12.028

17. Spravochnik po tipovym programmam modelirovaniia [Text]. Kyiv: Tehnika, 1980. - 184 p.

18. Ding, F. The model equivalence based parameter estimation methods for Box-Jenkins systems [Text] / F. Ding, D. Meng, Q. Wang // Journal of the Franklin Institute. - 2015. - Vol. 352, No. 12. - P. 5473-5485. doi:10.1016/j.jfranklin.2015.08.018

19. Alban, A. Efficient Monte Carlo methods for estimating failure probabilities [Text] / A. Alban, H. A. Darji, A. Imamura, M. K. Nakayama // Reliability Engineering \& System Safety. 2017. - Vol. 165. - P. 376-394. doi:10.1016/j.ress.2017.04.001

20. Theil, H. Applied Economic Forecasting [Text] / H. Theil. Elsevier Science Publishing Co Inc., 1966. - 503 p.

21. Bolshov, L. A. Prognozirovanie energopotrebleniia: sovremennye podhody i primer issledovaniia [Text] / L. A. Bolshov, M. F. Kanevskii, E. A. Savelieva et al. // Izvestiia RAN. Energetika. - 2004. - Vol. 6. - P. 74-92.

22. Wang, C. Parametric optimization of steam cycle in PWR nuclear power plant using improved genetic-simplex algorithm [Text] / C. Wang, C. Yan, J. Wang, C. Tian, S. Yu // Applied Thermal Engineering. - 2017. - Vol. 125. - P. 830-845. doi:10.1016/j.applthermaleng.2017.07.045

23. Khan Mashwani, W. Hybrid non-dominated sorting genetic algorithm with adaptive operators selection [Text] / W. Khan Mashwani, A. Salhi, O. Yeniay, H. Hussian, M. A. Jan // Applied Soft Computing. - 2017. - Vol. 56. - P. 1-18. doi:10.1016/j. asoc.2017.01.056

24. Javidrad, F. A new hybrid particle swarm and simulated annealing stochastic optimization method [Text] / F. Javidrad, M. Nazari // Applied Soft Computing. - 2017. - Vol. 60. P. 634-654. doi:10.1016/j.asoc.2017.07.023

25. Gordienko, E. K. Iskusstvennye neironnye seti I. Osnovnye opredeleniia i modeli [Text] / E. K. Gordienko, A. A. Lukianitsa // Tehnicheskaia kibernetika. - 1994. - No. 5. - P. 79-91.

26. Dorrer, M. G. Intuitivnoe predskazanie neirosetiami vzaimootnoshenii v gruppe [Text] / M. G. Dorrer; ed. by A. N. Gorban // Metody neiroinformatiki. - Krasnoiarsk, 1998. - P. 111-129.

27. Mihailov, M. Yu. Primenenie iskusstvennyh neironnyh setei dlia kratkosrochnogo prognozirovaniia nagruzki [Text] M. Yu. Mihailov // Metody upravleniia fiziko-tehnicheskimi sistemami energetiki sistemami energetiki v novyh usloviiah. Novosibirsk, 1995. - P. 82-86.

28. Leikin, V. S. Sistemnyi podhod k otsenke sudovyh elektroenergeticheskih kompleksov [Text] / V. S. Leikin, V. P. Nino // Sudostroenie. - 1974. - Vol. 3. - P. 41-44.

29. Haykin, S. Neural Networks: A Comprehensive Foundation [Text] / S. Haykin. - Ed. 2. - Prentice Hall, 1998. - 842 p.

30. Aksenov, S. V. Organizatsiia i ispol'zovanie neironnyh setei (metody i tehnologii) [Text] / S. V. Aksenov, V. B. Novoseltsev; ed. by V. B. Novoseltsev. - Tomsk: NTL, 2006. - 128 p.

31. Geman, S. Neural Networks and the Bias/Variance Dilemma [Text]/ S. Geman, E. Bienenstock, R. Doursat // Neural Computation. - 1992. - Vol. 4, No. 1. - P. 1-58. doi:10.1162/neco.1992.4.1.1 
32. Virianskii, Z. Ya. Sudovye sistemy avtomaticheskogo kontrolia (Sistemnyi podhod k proektirovaniiu) [Text] / Z. Ya. Virianskii, I. L. Kiselev, N. V. Kolesnikov. - Leningrad: Sudostroenie 1974. - 254 p.

33. Baranov, A. P. Sudovye avtomatizirovannye elektroenergeticheskie sistemy [Text] / A. P. Baranov. - Moscow: Transport, 1988. - 328 p.

34. Gaskarov, D. V. Prognozirovanie tehnicheskogo sostoianiia i nadezhnosti radioelektronnoi apparatury [Text] / D. V. Gaskarov, D. V. Golinkevich, A. V. Mozgalevskii. - Moscow: Sovetskoe radio, 1974. - $224 \mathrm{p}$.

35. NeuroPro: neironnye seti, metody analiza dannyh: ot issledovanii do razrabotok i vnedrenii [Electronic resource]. - Available at: \www/URL: http://neuropro.ru/

\section{ЛРОГНОЗИРОВАНКЕ РАБОТОСПОСОБНОСТИ СУДОВОЙ ЗЛЕКТРОЗНЕРГЕТИЧЕСКОЙ СИСТЕМЫ НА БАЗЕ ИСКУССТВЕННОЙ НЕЙРОННОЙ СЕТИ}

Разработана структура системы прогнозирования состояния судовой электроэнергетической системы (СЭЭС) на базе искусственной нейронной сети (ИНС). Решена задача обучения ИНС, используя данные, полученные в результате применения аналитических методов прогнозирования состояния СЭЭС. Доказана возможность применения ИНС для решения задач прогнозирования состояний СЭЭС.

Ключевые слова: прогнозирование состояния судовой электроэнергетической системы, коэффициент обобщенного параметра, искусственная нейронная сеть.

Gvozdeva Irina, Doctor of Technical Sciences, Professor, Department of Ship's Electrical Equipment and Automation, National University «Odessa Maritime Academy», Ukraine, ORCID: http:// orcid.org/0000-0003-2172-8888

Lukovtsev Valery, PhD, Associate Professor, Department of Ship's Electrical Equipment and Automation, National University «Odessa Maritime Academy», Ukraine, e-mail: femire@onma.edu.ua, ORCID: http://orcid.org/0000-0003-3673-5159

Tierielnyk Sergii, Postgraduate Student, Department of Ship's Electrical Equipment and Automation, National University «Odessa Maritime Academy»,Ukraine, e-mail: s.tierielnyk@gmail.com, ORCID: http://orcid.org/0000-0002-7661-9470 